om aan het secretariaat-generaal van de Nederlands-Belgisch-Luxemburgse Douaneovereenkomst een schriftelijke uiteenzetting van de moeilijkheden voor te leggen. Mr. Emmen Riedel bracht onder de aandacht van de vergadering de mogelijkheid van het in het leven roepen van studiecommissie's door de landelijke groepen; aan de Belgische groep werd daarbij in overweging gegeven een dergelijke commissie in te stellen ter bestudering van genoemde vraagstukken.

Ten slotte vestigde Mr. Emmen Riedel de aandacht op het werkterrein van de I.F.A., dat niet alleen het fiscale, doch ook het financiële recht omvat. Aan dit laatste ware meer aandacht te besteden, zoals reeds op de bestuursvergadering te Parijs naar voren werd gebracht.

\title{
FISCALE NOTITIES:
}

Nogmaals het Wetsontwerp Belastingherziening 1947 en de Onbelaste Reserve, door G. A. van Hout.

\section{Rectificatie:}

In het Julinummer, vgl. blz. 236, is in het door mij geschreven artikel, naar mij thans blijkt, een onjuistheid geslopen, die ik als volgt wil corrigeren.

Ik liet het daarin voorkomen als zou bij een onbelaste reserve van $f 30.000$, - berekend uit de hoger genoemde factoren en bij het bestaan van een H.O.R. groot $f$ 25.000, - slechts $f 5.000$, - ten laste van de winst mogen worden gereserveerd. Dit is echter onjuist, omdat de grens van de onbelaste reserve niet bepaald wordt door de H.O.R. uitsluitend, doch mede door de genoemde factoren. Het volgende voorbeeld diene ter verduidelijking.

\section{Balansgegevens:}

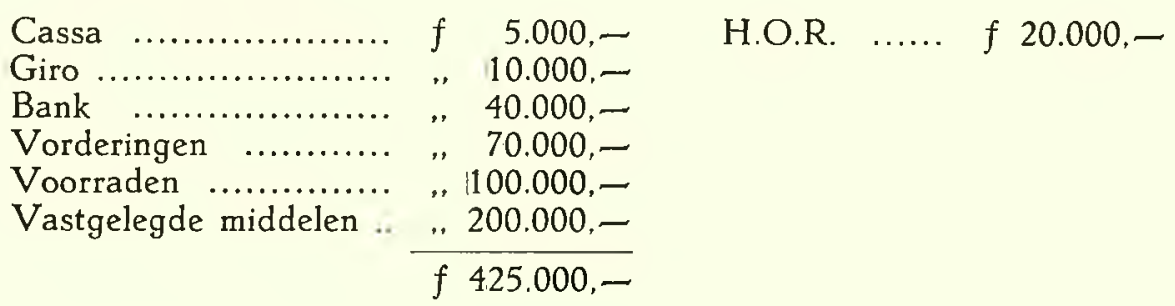

De winst over 1946 bedraagt $f$ 50.000, - .

Het maximum van de winst bedraagt nu $15 \%$ of $f 7.500,-$.

De keuze uit de factoren, $20 \%$ van de lichamelijk ezaken, welke voor de bedrijfsuitoefening worden gebezigd en $10 \%$ van de voorraden is $f 50.000$, - of $10 \%$ van de overige activa zijnde $f 125.000,-$ is $f 12.500$, - , leidt tot het bedrag ad $f 50.000,-$. Dit nu is de grens waarboven de onbelaste reserve niet mag uitgaan en waarop de H.O.R. nog in aftrek komt, zodat resteert $f 30.000$, - . In dit geval kan dus gereserveerd worden het bedrag ad $f 7.500$, - en in volgende jaren wederom een dusdanig bedrag als overeenkomt met de becijfering voortvloeiend uit 
gemelde factoren, onder aftrek van de bestaande H.O.R. in vergelijking met het maximum van de dan behaalde winst.

Het komt dus hierop neer, dat de H.O.R. in mindering wordt gebracht van het plafond, gevormd uit genoemde factoren, waarna de grootte der onbelaste reserve vaststaat, die vervolgens wordt vergeleken met het maximum van de winst. Is laatstgenoemde factor in enig jaar hoger dan die grootte, dan komt dit laatste bedrag ten laste van de winst. Is hij lager. dan dit lager cijfer.

De zaak ligt dus anders dan ik aanvankelijk in dit opzicht voorstelde. niet de onbelaste reserve wordt verminderd met de H.O.R. echter het plafond van de onbelaste reserve.

\section{REPERTORIUM VAN LITERATUUR OP HET GEBIED VAN ACCOUNTANCY EN BEDRIJFSHUISHOUDKUNDE}

Redactie: Centrale Documentatiedienst inzake bedrijfsorganisatie N.V. (C.D.B.)

\section{TIJDSCHRIFTENREPERTORIUM}

\section{A. ACCOUNTANCY}

\section{HET ACCOUNTANTSBEROEP}

\section{Business and professional training}

Hooper, F. C. - Korte beschouwing over de gevaren van specialisatie in het algemeen en van de accountantsopleiding in het bijzonder. Schr. betoogt dat de accountants-opleiding te beperkt is en te weinig ruimte laat voor cen brede algemene ontwikkeling, terwijl de student ook geen tijd heeft om hier zelf aan te werken. Algemeen wo:dt aanvaard dat een accountant door zijn theoretische keinnis en door het feit dat hij regelmatig in contact kont met allerlei categorieën van bedrijvigheid een inzicht krijgt in de problemen die zich in die verschillende bedrijven voordoen en op die wijze de capaciteiten verkrijgt voor een leidende positie in de industrie. Schr. betwijfelt dit sterk en dringt ann op cen uitbreiding van de accountantsopleiding in die zin dat de student geschikt gemaakt wordt voor de leidende arbeid. Tenslotte worden enkele suggesties gedaan om dit probleem op te lossen.
A II 3
Accountancy Nr. 640, December 1946

013.2

\section{LEER VAN DE CONTROLE.}

\section{Contrōle op het onderhoud in cen kleine fabriek}

Redactie - Korte uiteenzetting van cen eenvoudig georganiseerd controlesysteem. Twee regels dienen streng te worden gehandhaafd: geen onderhoudswerk zonder geschreven order en elke order moet worden onderworpen aan goedkeuring van de leiding. De ervaring van schr, is dat het beschreven systeem zeer effectief en economisch werkt.

A IV 1 Bedrijfseconomische mededelingen uit het buitenland 1, Nr. 2, 1946,47

\section{B. BEDRIJFSHUISHOUDKUNDE}

\section{a. ALGEMEENE BEDRIJPSHUISHOLIDKUNDE}

\section{ALGEMEEN.}

Verborgen wenken

Pla ats. Th. v. d. - Schr. zet kort en zakelijk uiteen dat met de emancipatie van de industrie en de enorme groei van de bedrijfshuishouding cok de problemen toegenomen 